\title{
SOCIOLOGICAL AND LEGAL ASPECTS OF "PRISON MOVIES" 1
}

\author{
Rudolf Kasinec, Tomáš Mészáros \\ Comenius University in Bratislava, Faculty of Law
}

KASINEC, R., MÉSZÁROS, T. Sociological and Legal Aspects of "Prison Movies". Bratislava Law Review, Vol. 3, No. 2 (2019), pp. 91 - 98. ISSN 2585-7088, eISSN: 2644-6359

\begin{abstract}
The paper focuses on the cinematic depiction of the various problems of the European and the American penitentiary systems.

The paper presents an analysis of two movies - one relating to civil European legal system and the other one from the area of American legal culture - on purpose. Our ambition was to compare two different approaches to prison theme and subsequently to illustrate the diversity of conditions in prisons facilities, the regress of individuals in "hostile" territory and others interesting but also unsettling consequences of life in prison.
\end{abstract}

Key words: movies, prison, prisoner, legal problems, punishment, law and art, legal theory, French penitentiary, American penitentiary, sociology, Présumé coupable, Shot Caller

\section{GENERAL REFLECTION ON PRISON}

It is a simple fact based on the common knowledge that the human body and mind are not designed for long-lasting loss of freedom. Therefore, it is crucial that the environment "behind the prisons walls" comply with the principles of humanity. However, the qualitative differences between prisons are enormous - in some countries (e. g. Scandinavian states) prisons reminds more of "scout camps" then state facilities and in other countries, prisons represent the worst social environment in the state (e. g. in Russia, Turkey, and Thailand). Following this context, this article aims to partially analyze following presumption: "Today's rational choice perspectives continue to assume that imprisonment reduces crime, but this assumption has not been proved-indeed, the majority of people released from prison on parole soon recidivate. Moreover, by interpreting crime solely as the result of individual choice, these theories deny the role in crime causation of poverty, race, class, and gender."

We assume the prison's condition always reflects the politics of state and values of the particular society. The correlation simply exists - we can identify the same problems on the state level as well in relation to the prisons: state/prison corruption, awful living conditions, the insignificance of human life, violations of human rights and freedoms, lack of money in national/prison budget. Before mentioned significant problems exist worldwide, even in the penitentiary system of western countries, where the prison system is considered to be "civilized". However, the real controversial situations occur in the confrontation with the "uncivilized" prison systems. Typical example of this "conflict" is the

\footnotetext{
1 The article was processed within the project VEGA 1/0859/18 "Limitation of the freedom of expression: case of "vault" movies."

2 RAFTER, N., BROWN, M.: Criminology goes to the movies: crime theory and popular culture, New York : New York University Press, 2011, p. 17.
} 
situation of the imprisonment of foreigners for smuggling or selling illegal drugs in some of the Asian countries (e.g. Thailand) - these convicts are confronted with a drastic environment in the local prisons that significantly differs from the civilized standards. This type of situation was an inspiration for many TV series (Bangkok Hilton, 1989; Banged Up Abroad, 2007) and movies (Dadah Is Death, 1988; Brokedown Palace, 1999; Return to Paradise, 1998; Ma fille est innocente, 2007; Midnight Express, 1978).

\section{PRISON, TV, AND MOVIE}

Cinematography has created various genres that directly reflect the reality and the genre of "prison movies" is one of them. The prison movies are relevant and also important sources of information on the issues of the crime, the punishment, the life in prison and life after releasing from a prison: "People have always been fascinated with punishment. In the past, they would gather in the town square to watch as wrongdoers were punished; however, in the late eighteenth century, most punishment moved behind prison walls. What took place there was a mystery to most. In the modern era, people often turn to the media and popular culture to feed their curiosity about this social institution. The prison film genre developed early in the history of moviemaking."3

Filmmakers and audiences alike have a morbid curiosity about what goes on behind the bars and this natural human fascination with the topic of punishment and imprisonment has led to a production of numerous TV shows and movies about life in prison:

i. TV shows: Orange is New Black, OZ, Prison Break, Wentworth, Bad girls, Porridge, Arrested development, Bangkok Hilton.

ii. Movies: Presumed Innocent, The Shawshank Redemption, Cell 211, The Green Mile, Cool Hand Luke, Brubaker, Papillon, Escape from Alcatraz, Felon

iii. Documentaries: The Biggest Prison System in History, Solitary Confinement, Prison Terminal: The Last Days of Private Jack Hall, Coming Home, Lost for Life, The House I Live In, American Chain Gang, Into The Abyss and a lot of other documentary films.

\subsection{Movies as a source of information about life in the prison}

Movies are not the only source of valuable information on crimes, victims, punishment, trial, jury, judge or prisoners, but they are also a powerful tool of prevention. A significant part of the human population has never been in a prison, they have never studied law or they have never worked in police forces. These people live their everyday stereotypes and they have never had problems with the law throughout an entire life. How is that possible? Intuitively we all respect legal norms but (in fact) we don't understand them so well. We don't recognize them in their complexity.

To solve this paradox, sociology has a crucial role: parenting, school education and other sociological aspects of our life. Culture and religion are also a very important element in human life. The religion operates with religious norms that are very similar to legal norms (e.g. in Christianity "Thou shalt not kill", “Thou shalt not steal" and others).

3 OLESON, J.: Dawn K Cecil, Prison life in popular culture: From the Big House to Orange is the New Black, In: Australian \& New Zealand Journal of Criminology, Vol 49, Issue 2, 2015, pp. 303 - 305. Available at https://doi. org/10.1177/0004865815616535 [q. 2019-12-10]. 
The culture forms human character through TV, songs, theatres, movies, paintings, architecture, popular literature and other forms of art. We can observe a crime, life in prison and after prison in TV-shows, movies, theatres. We can read about victims, murders, punishments in popular books, comics, and magazines.

"Imprisonment is a widespread punishment all over the world, but prison is for most of us an unknown experience and anything we know is mostly, through media and cinema representations. Therefore, it is very likely these representations play an important role in the formation of our social representation for this matter. Additionally, the audience captivated for issues which are unknown and unreachable and that relate to the criminal behavior and action of institutions of social control of crime, but also to life in prison." 4 Movies have an important, even essential role as a prevention tool. The audience sees the awful condition in prisons and this visual experience could discourage them from committing a crime.

\section{EUROPEAN PERSPECTIVE - LIFE IN THE PRISON AND AFTER}

Most of the people have misleading illusions about life in a prison. They respect legal norms and they have never had a problem with state authority. Consequently, these people have never seen a prison from inside. The logical question arising from this fact is this: "how could the deterrence effect of imprisonment effectively work if most of the people perceive the life in prison distorted"?

The possible key for solving this inconsistency could be connected to popular culture, mostly to movies. Movies about prison, punishment or crime are very popular and interesting, especially among European audience. We can identify a large group of European movies dealing with life in prison and after the imprisonment, concretely from these states:

- Germany: Das Experiment, Baader Meinhof Komplex;

- France: Présumé coupable, Le trou, A Man Escaped or The Wind Bloweth Where It Listeth;

- Denmark: Anklaget; $R$

- Italy: A Prophet; Caesar Must Die

- Turkey: Midnight Express;

- Great Britain: In the Name of the Father, Bronson, Scum, Starred up, Ghosted;

- Spain: Cell 211;

- Romania: Bless You, Prison;

- Poland: Interrogation;

- Austria: Breathing;

- Czech republic: Kajinek

- Ireland: Maze

- Slovakia: Comeback

This index contains only a small percentage of many movies showing the concept of a life behind bars in different European countries. The variety of movies helps to comprehend the diversity of national concepts of the imprisonment. The audience can find a lot of detailed information about national specifics, related not only to "jail issues", but also to social and religious values.

4 BOUGADI S. G.: Fictional Representation of Prison in Films and TV's Series Genre: Public and Academic Perceptions of Prison, In: Forensic Research \& Criminology International Journal, Vol. 2 Issue 1, 2016. 


\subsection{A short analysis of a European movie: Guilty (Présumé coupable, France - Denmark, 2011)}

The French movie Présumé coupable (Guilty) could be easily considered as one of the most powerful and influential contemporary French movies. The narrative of the movie is uncompromising "Guilty" grabs the audience from the beginning and does not let it go - much like the French legal system. The plot of the movie revolves around the story of the most infamous miscarriage of justice in modern-day France.

The movie focuses on actual events and in its center is the main protagonist Alain Marécaux who was one of the innocent defendants in the famous case called "Outreau trial". The movie is a reconstruction of the events according to Alains memoirs. The movie tells the story of a man who was wrongfully convicted of sexual abuse against children and then taken to prison. It is also a story of a man who lost everything: his family, job, house, property, dignity, and health. The movie even shows his desperate attempt to commit suicide in prison and his protest (hunger strike). The viewer can see how devastating effect has the imprisonment on a human.

This movie could be very effectively used for various pedagogical and academic purposes as it enables us to demonstrate the harsh conditions in prisons, to illustrate various ethical and moral dilemmas or question the effectiveness and fairness of the system of justice. All these (and even more) problematic issues could be discussed either with the students or during academic debates.

\section{$4 \quad$ AMERICAN PERSPECTIVE - LIFE IN THE PRISON AND AFTER}

In the American cinematography - both in the commercial distribution and in independent European-like art cinematic production - has the theme of "imprisonment" an important position. Suffice to mention that the most popular and/or best American movie of all the time - The Shawshank Redemption - is a prison movie.

In the American perspective, one specific feature of the prison-centric films is prominent: "More recent cinematic images have provided a sharp contrast to hopeful challenges against a toxic prison authority. Indeed, in these films, the inmates themselves have become poisonous against each other in the context of a faceless prison machine that has as its sole function their containment. This was clearly seen in American History X, American Me, and Escape from New York, with ethnic/racial gangs fighting for power and governing the nature of one's life and survival. For instance, when Derek walked away from the Aryan Brotherhood in American History X, he suffered the consequence of a brutal rape and, then, survived only because he, unknowingly, had the more powerful African American Brothers on his side."

The American prison movies illustrate not only the negative aspects (and impacts) of the nonfunctional penitentiary system on the individual but also outlines the inevitable destructive effects of the prison's environment itself. One of the best example of the movie about incarceration that successfully treads the fine line between realism and sensationalism and presents the complexity of the negative impacts of the imprisonment is the movie called "Shot Caller."

5 ROCKELL, B.A.: Theoretical and Cultural Dimensions of the Warehouse Philosophy of Punishment, In: Journal of Criminal Justice and Popular Culture, vol. 16, issue 1. Available at https://www.albany.edu/scj/jcjpc/jcjpc_vol16.html [Watched 22. 3. 2018]. 
Shot Caller is a 2017 American crime thriller film directed and written by Ric R. Waugh. The film chronicles the transformation of a well-to-do family man and successful, white-collar businessman into a hardened prison gangster, undergone to survive California's penal system after he is incarcerated for his role in a deadly car accident (actually sentenced to jail for involuntary manslaughter and driving under influence). Subsequently, over the course of ten years in prison, the "human animal" emerges in the main protagonist Jacob - he becomes a ruthless savage, a reluctant pawn in the corrupt, unorganized U.S. prison system. Shocked by the brutality of prison life, Jacob follows his lawyer's advice to stand his ground. He attacks an African-American inmate when provoked, drawing the attention of white power gang closely affiliated with the Aryan Brotherhood. In return for protection and entry into this gang, Jacob is forced to smuggle heroin and kill a "snitch" within the gang. As the story progress, Jacob falls, even more, deeper into the binding structures of the prison society and he is forced to commit various brutal actions. At the end of the movie, Jacob as fully validated gang member is sentenced to life imprisonment with no possibility of parole (due in part to California's three strikes law).

The film takes a heavy dose of inspiration from another famous movie - American History X and it focuses on the idea that actions in prison heavily affect upon your life outside. It is undoubtedly a realistic portrayal of a flawed, regressive penal system that not only focuses on punishment over rehabilitation and treatment for its guilty inmates, but forces morally sound human beings to do the unspeakable to survive. The film leaves you with a sense that the system has irreparably ruined Jacob's life and the lives of the people he loves.

In the final act of the movie, Jacob starts to study and read books (mostly philosophy, e.g. the book The Prince by Niccolò Machiavelli is placed on his bookshelf). An interesting fact is that his selection of literature includes a fictitious book titled The Human Animal. This title of the book sounds is actually based on a real novel written by anthropologist Raoul W. La Barre. The main idea of this book is the opinion, that "man" is closer to its primate ancestor than we think, and that social constructs and appropriate human behavior are simply superfluous, evolutionary defects in our species. In placing this subtext within the movie Shot Caller, we can observe the life-threatening necessity for the immediacy of Jacob's adjustment in prison society to survive his lengthy sentence, i.e. the necessity to became "animal".

For an open-minded audience is the movie Shot Caller a depth-inside exploration of the animalistic nature in humanity through the shortcomings of the American penal system.

\section{$5 \quad$ MOVIES ON PRISON AND THEIR SOCIOLOGICAL EFFECTS ON PEOPLE}

Another very stimulating (also important) alternation of the previously raised question could be the following: Are the movies, TV-shows, and documentaries able to prevent crimes? Answer to this question is once again very complicated, but we could try to outline the basic approaches of the solutions.

In general, media have a substantial influence on human behavior in modern society. Media, including movies, tell us captivating stories and thus they considerably form our opinion to politics, society, culture and ordinary life.

Media and the internet have enormous influence in every European country. Freedom of speech and the right to be informed are one of the most precious human (political) rights in the European 
Union. This "gift" has brought unfortunately also burdens - the people have everyday dilemmas with conceiving so much information and they often fail to select which are relevant, important or reliable (the outcome of this is the popularity of the phenomenon of fake news). The media (movies included) should ease the complicated situation and provide a guide. It relates also to movies on life in the prison - these movies could affect our opinion in the same way.

In theory, the media combines three essential communication levels in the process of social perception of prisons:

i. devising, giving general background of prison or showing reactions of the community.

ii. comparison, allowing the 'benchmark', both for moral elevation and the authenticity and sets the limits of acceptance pressing behavior and

iii. the prism through which we 'see' the prison. With other words, the films reflect the academic explanation: this display of media forming our social construction of reality in a way that distorted reality. ${ }^{6}$

On the contrary, the influence of the movie and its social impact could be, indeed, distortionary (concerning reality). The content of the prison movies could be not only informative and educational but potentially also "toxic" and dangerous. The hidden risk within the prison movies is related to the fact these movies often depict prisoners (i.e. convict) as a dramatic heroes: "For instance, the public now demonstrates its willingness to heroize individuals simply for violence, such as Charles Bronson, who is reputed to be the most violent prison inmate and serial hostage taker in Britain. Bronson is heroized for his strength and dangerousness that has led to him spending 24 years in solitary and making him into a form of anti-hero consolidated by the 2009 movie Bronson. In the culture-industry age, criminal-celebrity is becoming corrupted, allowing criminals such as Bronson to become heroized without the gentlemanly characteristics of the original criminal-hero cases." ${ }^{7}$ For the broader context of the example with Charles Bronson is worth to mention that he was also played by a popular and charismatic British actor Tom Hardy, whose portrayal of the notorious killer encouraged many viewers to sympathize with the character.

On the other hand, the prison movies also represent an important visual display of the negative sociological and psychological impact of imprisonment (and the negative influence of the prison's environment) on the inmates. This aspect is even more impactful in the movies in which the story revolves around common, normal people who have been imprisoned for the first time and/or as the result of an unfortunate event (e.g. in the movie Shot Caller). After few years in prison, these people have become dangerous criminals without normal life perspective. This scenario is presented in movies like Felon (USA, 2008), Prophet (France, 2009), Shot Caller (USA, 2017) or Brawl in Cell Block 99 (USA, 2017). From the sociological point of view, these types of prison movies indirectly question the efficiency of the penitentiary system itself.

The prison movies frequently demonstrate also another problematic aspect of everyday life inside the prison walls. These movies, respectively the narrative of these movies often implement the element of the carrot and stick' approach: "Prisoners receive token rewards when they conform to the rules on the theory that eventually conformity will become habitual. A second type of behavior modification-aversive conditioning-uses loud noises, drugs that induce vomiting or paralysis, and elec-

6 BENNETT, J.: The Good, the Bad and Ugly: The Media in Prison Films. In: The Howard Journal of Criminal Justice 45(2), 2006, p. $97-115$.

7 PENFOLD-MOUNCE, R.: Celebrity Culture and Crime: The Joy of Transgression, New York: PALGRAVE MACMILLAN, p. 86. 
troshock to discourage prisoners' deviant behaviors. This is the type depicted in A Clockwork Orange." The method of the stick is dominant in most of the prison movies. Hard work, torture, violence, corruption, fights, rape, solitary cell and many other inhumane instrument are presented in prisoncentric films, often in very explicit and vivid images. These components of the movie may challenge the trust of the viewers in the state institutions.

The last specific topic that is inspiring from the sociological and also philosophical point of view and is often addressed in the prison movies is the so-called "Stanford prison experiment". It is one of the most famous academic experiments in the world and the amount of the filmographic reproduction of this experiment is numerous. ${ }^{9}$ The topic of these movies is interesting not only in relation to the impact of the prison environment on the inmates but also regarding the psychological influence on the guards.

This chapter presented the most frequent and at the same time, the most interesting topics in the prison movies. The role of academics is essential in analyzing and solving the summarized problems in the thematic area of the movies on the imprisonment. Thus, the main goal of this paper was to identify and pinpoint which movies are particularly important and which illustrate most accurately the actual life in a prison, the relations between prisoners, the social order in a prison and the life of the inmates after leaving the prison.

\section{PAST, PRESENT AND FUTURE IN IMPRISONMENT POLICY}

The popular culture allows us to easily compare the prison systems and their functionality in the past and the present. Especially the movies on actual events are valuable and inspiring for academic purposes. Directors often reinterpret true stories about people in complicated life situations (loss of freedom, dignity, health, family and even of future perspective). Undoubtedly, a prison is a complicated "closed" world designed for a life of a strictly limited group of people. It is a specific type of human society could be entitled as a "prison society".

A prison society functions on actual rules, on a system of own values and social norms made by prisoners. The story-line of prison movies is always located in a particular prison existing in the specific time. Based on the assumption that we are able to determine the historical background of the movie, we could compare the current actual situation in prisons with the condition in prisons of the past.

By application of the same methodology (determination of the context - contextual comparison), we could effectively compare different aspects of imprisonment not only through the time but also through (geographical) space, i.e. in different European countries. This idea (method) is a solid proof of the usefulness and practicality of the sociological and legal analysis based on the analysis of the prison movies that were presented in this paper.

8 RAFTER, N., BROWN, M.: Criminology goes to the movies: crime theory and popular culture, New York: New York University Press, 2011, p. 49.

9 Examples of this type of movie includes documentary movie called Quiet Rage: The Stanford Prison Experiment (USA, 1992) and three live-action movies. First one was produces in Germany in 2001 and it was inspired directly with this experiment. Its remake was consequently shot in USA in 2010 and leading roles were cast Adrien Brody as one of prisoners and Forest Whitaker as one of guardian in "fake" prison. The last movie was produced in 2015 and its reconstruction of events from real Stanford experiment and name of movie is very straightforward - The Stanford Prison Experiment. 
The paper presents analysis of two movies - one relating to civil European legal system and other one from the area of American legal culture - on purpose. Our ambition was to compare two different approaches to prison theme and subsequently to illustrate the diversity of conditions in prisons facilities, the regress of individuals in "hostile" territory and others interesting but also unsettling consequences of life in prison.

\section{Bibliography:}

BENNETT, J. The Good, the Bad and Ugly: The Media in Prison Films. In: The Howard Journal of Criminal Justice 45(2), 2006, p. 97-115.

BOUGADI, S. G. Fictional Representation of Prison in Films and TV's Series Genre: Public and Academic Perceptions of Prison, In: Forensic Research \& Criminology International Journal, Vol. 2 Issue 1, 2016.

OLESON, J., DAWN, K. C. Prison life in popular culture: From the Big House to Orange is the New Black, In: Australian \& New Zealand Journal of Criminology, Vol 49, Issue 2, 2015, pp. 303 - 305.

PENFOLD-MOUNCE, R. Celebrity Culture and Crime: The Joy of Transgression. New York: PALGRAVE MACMILLAN, p. 86.

RAFTER, N., BROWN, M. Criminology goes to the movies: crime theory and popular culture, New York: New York University Press, 2011.

ROCKELL, B.A. Theoretical and Cultural Dimensions of the Warehouse Philosophy of Punishment, In: Journal of Criminal Justice and Popular Culture, vol. 16, issue 1.

\section{Contact information:}

doc. JUDr. Rudolf Kasinec, PhD.

rudolf.kasinec@flaw.uniba.sk

Comenius University in Bratislava, Faculty of Law

Šafárikovo nám. č. 6

P. O.BOX 313

81000 Bratislava

Slovak Republic

JUDr. Mgr. Tomáš Mészáros, PhD.

tomas.meszaros@flaw.uniba.sk

Comenius University in Bratislava, Faculty of Law

Šafárikovo nám. č. 6

P. O.BOX 313

81000 Bratislava

Slovak Republic 